\title{
Chemical composition, energy and biological value of broiler chicken meat caused by various doses of selenium
}

\author{
O.I. Sobolev ${ }^{1}$, B.V.Gutyj ${ }^{2}$, S.V. Sobolieva ${ }^{3}$, O.O. Borshch ${ }^{1}$, V.A. Liskovich ${ }^{1}$, O.I. \\ Prystupa $^{2}$, N.V. Demus ${ }^{2}$, O.R. Paladiychuk ${ }^{4}$, O.V. Fedorovych ${ }^{2}$, E.I. Fedorovych5 ${ }^{5}$ I.I. \\ Khariv', R.O. Vasiv', N.D. Levkivska², K.Y. Leskiv², Z.A. Guta $^{2}$ \\ ${ }^{1}$ Bila Tserkva National Agrarian University, Bila Tserkva, Ukraine \\ 2 Stepan Gzhytskyi National University of Veterinary Medicine and Biotechnologies Lviv, Ukraine \\ ${ }^{3}$ Bila Tserkva Institute of continuous professional training, Bila Tserkva, Ukraine \\ ${ }^{4}$ Vinnytsya National Agrarian University, Vinnytsya, Ukraine \\ ${ }^{5}$ Institute of Animal Biology NAAS, Lviv, Ukraine \\ E-mail: bvh@ukr.net
}

\section{Received 23.10.2019 Accepted 02.12.2019}

\begin{abstract}
From the standpoint of modern ideas, the normal functioning of the poultry body and full implementation her of the genetic potential is impossible without the presence of selenium in the diet. The biochemical diversity of selenium puts it in a number of priority trace elements. Scientists who were studying the effects of selenium on poultry body and paid relatively little attention to the quality of the meat. In scientific experiment are studied the effect of additives different doses of selenium in compound feed on the chemical composition, energy and biological value of meat of the cross chickens-broilers COBB 500. Introduction of selenium into the feed for broiler chickens in the doses which are studied $(0.3 \mathrm{mg} / \mathrm{kg}, 0.4$ and $0.5 \mathrm{mg} / \mathrm{kg})$ didn't significantly affect to the quality of their muscle tissue although it positively affected on some indicators that characterizing its chemical composition, nutritional and biological value. Among the experimental groups, the best meat quality indicators were in the second group of chickens for which was introduced into the feed selenium from the calculation of $0.3 \mathrm{mg} / \mathrm{kg}$. When feeding mixed feeds with selenium additives to broiler chickens it was found that it is likely to increase the concentration of this trace element in muscle tissue by $60.6-100 \%(P<0.001)$, which doesn't exceed the maximum permissible level $(\mathrm{MPL})$. Consumption of selenium-enriched meat of broiler chickens within the limits of the physiological norms recommended in Ukraine will ensure the daily requirement of an adult in this trace element by $23.6-29.4 \%$. This meat product can be especially useful for people who live in regions with low levels of selenium in the natural environment.
\end{abstract}

Key words: Selenium; Compound feed; Broiler chickens; Meat; Chemical composition; Nutritional value

\section{Introduction}

Among the numerous elements of the technological process of growing young poultry for meat which ensure its high productivity and viability as well as the proper payment of feed with high-quality products and important role is given to full-fledged feeding.

The modern system of normalized feeding provides full satisfaction of the individual poultry needs in metabolic energy, nutrients and biologically active substances including trace elements. Full-fledged feed for poultry is impossible to imagine without guaranteed additives of trace elements. In different countries the same trace elements are added to poultry compound feeds and even at about the same doses. However, periodically the norms for the introduction of trace elements in feed for poultry are revised and refined taking into account new achievements of science and practice. Selenium is one of the trace elements that attract the attention of scientists and specialists of the poultry industry. According to the modern classification of trace elements which are based on their biological significance for the organism and influence on the immune system selenium belong to the group of vital (Kudrin et al., 2000).

Selenium is contained in the body in small quantities performs unique multifaceted functions such as catalytic, structural, regulatory in the process of which it activates the action of many enzymes, vitamins, hormones and thus ensure the normal functioning of various biological systems the implementation of numerous physiological and biochemical reactions in a living organism (Reilly, 2013).

According to the results of numerous studies are conducted on various species of farm animals and poultry that selenium has antioxidant, anti-carcinogenic, radio protective, immunostimulatory, antiviral and antitoxic properties. There is direct evidence of the effect of selenium on osteogenesis, reproductive function, growth and development processes (Surai \& Fisinin, 2014; Sobolev et al., 2018; Gutyj et al., 2019; Sobolev et al., 2019; Ashraf et al., 2019). Thus from the standpoint of modern ideas the normal functioning of the poultry's body and its full implementation of the genetic potential impossible without the presence of selenium in the diet. Despite the biochemical complexity of this trace element selenium has not used enough yet in the feeding poultry in Ukraine. This is due to the inconsistency of differentiated norms of its introduction into feed for poultry of different species, age and direction of productivity.

Analysis of available literature sources show that published data is not enough on the optimal rates of selenium introduction into feed for broiler chickens. However, it's known that the minimum requirement for selenium of all types of poultry is $0.08-0.10 \mathrm{mg} \mathrm{kg}^{-1}$ of feed. Scientifically standards are based of the introduction selenium in feed for broiler chickens that developed in different countries of the world they have differences. Scientists of the all-Russian research and engineering Institute of poultry breeding recommend to enrich feed for broiler chickens with selenium at the rate of $0.2 \mathrm{mg} \mathrm{kg}^{-1}$. The same opinion is shared by their colleagues from Germany. 
Scientists of the company "Cobb" (England) note that the diet of broiler chickens should contain selenium in feed at least 0.3 mg kg ${ }^{-1}$. Another British poultry breeding company "Aviagen" believes that to achieve high productivity of broiler chickens it is sufficient to introduce in the feed of selenium of $0.15 \mathrm{mg} \mathrm{kg}^{-1}$. Experts from the Czech company "Biofactory" came to the conclusion that $1 \mathrm{~kg}$ of feed for broiler chickens need to enter of $0.17 \mathrm{mg}$ selenium. According to the Belgian company "Vitamex" the rate of introduction selenium in feed for broiler chickens during the growth period of $1-10$ days compose $0.25 \mathrm{mg} \mathrm{kg}^{-1}, 11-24$ days is $0.3 \mathrm{mg} \mathrm{kg}$ and before slaughter 25 days is $0.375 \mathrm{mg} \mathrm{kg}^{-1}$. Ukrainian scientists believe that broiler chickens should receive selenium additive in feeds in the amount of $0.25-0.30 \mathrm{mg} \mathrm{kg}^{-1}$ throughout the growing period. According to the recommendations of the Ministry of Agriculture and Food Products of the Republic of Belarus the level of selenium in the diets of broiler chickens should be $0.5 \mathrm{mg} / \mathrm{kg}$ of feed. At the same time, Canadian researchers claim that the norm of selenium in complete feed for chickens should not exceed of $0.3 \mathrm{mg} \mathrm{kg}$.

In recent years in scientific publications there are publications of various authors who believe that the level of selenium in the diet affects on some indicators of the quality of broiler chicken's meat (Wang et al., 2011; Yang et al., 2012; Boiago et al., 2014; Oliveira et al., 2014; Bakaeva et al., 2015). The researchers were primarily interested in the physical and chemical parameters of meat the deposition of selenium in muscle tissue and internal organs. The influence of additives of different doses of selenium in feed for broiler chickens on the chemical composition of their meat, its energy and biological value hadn't been studied.

\section{Materials and Methods}

Experimental research was carried out on broiler chickens cross COBB 500. For carrying out scientific and economic experiment was formed four groups with daily young growth on 100 heads in each groups on the principle of analogues. The duration of the experiment was 42 days and corresponded to the period of growing young animals for meat. According to the existing norms of feeding chickens from daily to 42-day age was carried out by dry complete compound feeds which are balanced on the basic nutritious and biologically active substances. Poultry of the first control group didn't receive selenium additive in feed. According to the scheme of the experiment in the feed of poultry of the experimental groups additionally introduced different amounts of selenium (Table 1).

Table 1. Scheme of scientific experiment.

\begin{tabular}{cc} 
Group & Selenium supplement in complete feed, $\mathbf{m g} / \mathbf{k g}$ \\
1 Control Group & Complete feed - CF \\
2 Experimental Group & $C F+0.3$ \\
3 Experimental Group & $C F+0.4$ \\
4 Experimental Group & $C F+0.5$ \\
\hline
\end{tabular}

Selenium in feed for broiler chickens was taken as part of the mineral premix. As a source of selenium used sodium selenite classification of " $\mathrm{H}$ " (TU 6-09-17-209-88 registered in the identifier of chemical compounds (CAS) under the number 10102-18-8). The poultry were kept on the floor (on the same litter). Access to feed and water was free. Technological parameters of cultivation in all groups were identical and corresponded to existing norms which are recommended for broilers (Galibarenko et al., 2005).

At the end of scientific experiment in 42 days of age were selected 4 heads of poultry from each group and their control slaughter was carried out. After the control slaughter of broiler chickens a complete anatomical disassembly of their carcasses were performed according to the existing guidelines (Lukashenko, 2013).

During anatomical disassembly and collapse of the carcasses of broiler chickens were carried out by the selection of medium samples of muscle tissue (thigh muscles, shin and chest muscles) were taken for chemical analysis (GOST 7702.2.0-95, 2009).

Determinations of the chemical composition of the muscle tissue of broiler chickens were carried out by the following methods:

- mass fraction of moisture-by drying the sample in a drying oven at a temperature of $100-105^{\circ} \mathrm{C}$ to a constant mass (DSTU ISO 1442:2005, 2008);

- Mass fraction of nitrogen and protein by Kjeldahl method (DSTU ISO 937:2005, 2007);

- Mass fraction of fat - extraction with ethyl alcohol in Soxhlet apparatus (DSTU ISO 1443:2005, 2007);

- Mass fraction of ash - by burning the sample in a muffle furnace at a temperature of $525-550{ }^{\circ} \mathrm{C}$ (DSTU ISO 936:2008, 2010 ).

The energy value (E) of broiler chicken meat was determined according to the existing methodology (Metodika viznachennja himichnogo skladu ta energetichnoï cinnosti produktiv harchuvannja, 2000) and calculated by the formula:

$$
E=[S-(Z h+Z)] \times 4,0+(Z h \times 9,0),
$$

where $\mathrm{S}$ is the dry matter content in meat, \%; $\mathrm{Zh}$ - fat content in meat, \%; $\mathrm{Z}$ - ash content in meat, \%.

The relative biological value of meat was determined by micro method using a test organism of Tetrahymena pyriformis infusoria strain $\mathrm{WH}_{14}$ (Mikitjuk et al., 2004). Determination of the concentration selenium in muscle tissue was carried out by atomic absorption method on the spectrophotometer "Saturn-3 P1". Sample preparation (wet mineralization) was carried out according to the existing method (Holak, 1980).

The intensity of biological accumulation of selenium in the muscle tissue of broiler chickens were estimated by the accumulation coefficient (AC) which was calculated by the formula:

$$
\mathrm{AC}=\mathrm{C}_{m} / \mathrm{C}_{f}
$$

where $\mathrm{C}_{m}$ - the content of selenium in the muscle tissue of broiler chickens, $\mathrm{mg} / \mathrm{kg}$ of fresh tissue; $\mathrm{C}_{f}-$ the dose of selenium in feed, $\mathrm{mg} \mathrm{kg}^{-1}$.

Computer programs of statistical processing Microsoft Excel were used for mathematical processing of research results. The reliability of difference between the groups was assessed by Student's t-test.

\section{Results and Discussion}

The study of the chemical composition of the muscle tissue of broiler chickens of the control and experimental groups didn't reveal a significant difference between them. However, according to the majority of indicators that characterize the nutritional value of meat can be traced the advantage of young animals have grown on mixed feeds which included selenium (Table 2). The study of muscle 
tissue samples showed that broiler chickens of the experimental groups generally had slightly better chemical indicators of meat quality and some indicators were at the level of the control group. Despite the absence of a significant difference between the groups for most indicators that characterized the nutritional value of meat, the nature of the deposition of protein, fat and ash in the muscle tissue of young animals of the experimental groups in a certain way indicates the influence of selenium supplements.

Table 2. Chemical composition, energy and biological value of muscle tissue of broiler chickens, (mean + standard deviation, $n=4$ ).

\section{Groups}

\section{Indicators}

\begin{tabular}{lcc} 
The dry matter content, $\%$ & $25.8 \pm 0.16$ & $26.1 \pm 0.21$ \\
Protein & $19.4 \pm 0.09$ & $19.6 \pm 0.15$ \\
Fat & $4.1 \pm 0.21$ & $4.4 \pm 0.12$ \\
Ashes & $1.2 \pm 0.04$ & $1.3 \pm 0.05$ \\
Energy value, kcal $100 \mathrm{~g}^{-1}$ & $119.0 \pm 1.18$ & $121.4 \pm 1.25$ \\
The number of grown ciliates, units $\mathrm{ml}^{-1}$ & $8.28 \pm 0.225$ & $8.47 \pm 0.047$ \\
Relative biological value,\% & $\times 10^{4}$ & $\times 10^{4}$ \\
The concentration of selenium, $\mathrm{mkg} \%$ & 100.0 & 102.3 \\
\hline
\end{tabular}

Note. The probability of difference between the control and experimental groups

\section{Control 2 Experimental 3 Experimental 4 Experimental}

$\begin{array}{cccc}25.8 \pm 0.16 & 26.1 \pm 0.21 & 26.0 \pm 0.06 & 25.9 \pm 0.16 \\ 19.4 \pm 0.09 & 19.6 \pm 0.15 & 19.4 \pm 0.11 & 19.4 \pm 0.22 \\ 4.1 \pm 0.21 & 4.4 \pm 0.12 & 4.3 \pm 0.16 & 4.2 \pm 0.13 \\ 1.2 \pm 0.04 & 1.3 \pm 0.05 & 1.2 \pm 0.07 & 1.2 \pm 0.02 \\ 119.0 \pm 1.18 & 121.4 \pm 1.25 & 120.6 \pm 0.86 & 120.0 \pm 1.07 \\ 8.28 \pm 0.225 & 8.47 \pm 0.047 & 8.51 \pm 0.121 & 8.39 \pm 0.151 \\ \times 10^{4} & \times 10^{4} & \times 10^{4} & \times 10^{4} \\ 100.0 & 102.3 & 102.8 & 101.3 \\ 7.1 \pm 0.11 & 11.4 \pm 0.46^{* * *} & 13.5 \pm 0.19^{* * *} & 14.2 \pm 0.14^{* * *}\end{array}$

The results of the chemical analysis showed that the amount of total moisture in the muscle tissue of the poultry of experimental groups tended to decrease due to an increase in the dry matter content. So, if the content of dry matter in the meat of young animals of the control group was $25.8 \%$, then their peers from the second experimental group it was higher by $0.3 \%$, the third group by 0.2 and the fourth group by $0.1 \%$.

The increase in the dry matter content in the muscle tissue of broiler chickens of the second experimental group was due to a slight increase in the content of protein, fat, ash in the third and fourth experimental groups only fat. In terms of protein content the young poultry of the second experimental group exceeded by $0.2 \%$ their peers from the control and other experimental groups where the same figure was $19.4 \%$. The level of fat in the meat of young animals of the second experimental group was $0.3 \%$ higher, the third group was 0.2 and the fourth was $0.1 \%$ higher than that of poultry of the control group (4.1\%).

The ash content in the muscle tissue of the control and experimental groups were almost the same. In the control group and in the third and fourth experimental groups this indicator were at the same level (12.0\%). In young poultry of the second experimental group was higher by $0.1 \%$.

On the basis of data on the chemical composition of meat was determined by its caloric content. Since the caloric content of meat is largely determined by the content of protein and fat, therefore, this figure was slightly higher in the poultry of the experimental groups. Calculations showed that the energy value of $100 \mathrm{~g}$ of muscle tissue in broiler chickens of the second experimental group was $121.4 \mathrm{kcal}$, in the third group was 120.6 and the fourth group was $120.0 \mathrm{kcal}$, which is $2.0 \%, 1.3$ and $0.8 \%$ more than in the control group. One of the reliable criteria for assessing the quality of animal products, including poultry meat it is the biological value of the product, which is determined by its harmlessness, organoleptic properties, nutritional value, biological activity.

For express methods of determining the biological value of the product one of the most convenient and promising test objects is considered the Tetrahymena pyriformis ciliated. The criterion of the relative biological value of meat is the number (expressed as a percentage) of infusoria grown in three days in experimental samples in relation to the number of cells grown in control samples. Evidence of non-toxicity meat is the lack of dead ciliates and any pathological changes of Tetrahymena pyriformis during the period of incubation. The obtained results indicate that the relative biological value of muscle tissue of broiler chickens in the experimental groups in comparison with the control group increased by $1.3-2.8 \%$. It should also be noted that in the samples of young poultry meat of the control and experimental groups didn't find dead or deformed ciliates which indicates the absence of toxicity of these samples. Our results agree with the data of other scientists who studied the effect of selenium preparations on the qualitative composition of broiler chicken meat and noted a slight increase in the content of dry matter, protein and ash. However, the data they obtained on the content of fat is contradictory. According to some data, the fat content in the meat of young poultry with the introduction of additional amounts of selenium in the diet tended to increase (Ponomarenko, 2007) and according to others to decrease (Rassolov et al., 2008). There are also reports that due to the selenium supplement at a dose of $0.25 \mathrm{mg} / \mathrm{kg}$ of feed that are improved the chemical composition of broiler meat can increase its caloric content by 2.9\% (Kornilova \& Belova, 2008). This once again confirms our data and the general conclusion that the nutritional value of meat depends on the content of essential nutrients, particularly protein and fat. Scientists had studied the relationship selenium with the quality of slaughter products of broiler chickens and they also believe that its additives in feed increase the relative biological value of meat (Ponomarenko, 2007; Shackih, 2009). On the one hand the increase in the biological value of meat under the action of selenium is probably explained by changes in the content and profile of essential amino acids in proteins and fatty acid composition of lipids, on the other hand it's explained by slowing down the oxidation of proteins and unsaturated fatty acids that included in the lipid composition as well as the destruction of already formed peroxides. Our conclusion is consistent with the literature data (Bokova \& Birjukova, 2007; Kruk et al., 2007; Suraj \& Papazjan, 2007). In that the main source of selenium in the human body is food products, firstly we were interested safe food hygiene its concentration finds in the meat of broiler chickens and secondly whether it is possible at the expense of selenium-enriched meat to correct the selenium status of the population of Ukraine.

The results of the meat analysis for the content of selenium showed that it found in all the samples that were studied. The obtained data allowed us to establish that with the increase in the level of selenium in mixed feeds its concentration in the muscle tissue of broiler chickens also increased. So, if this indicator in the young poultry of the control group was equal to $7.1 \mathrm{mkg} \%$, then their peers from the second experimental group was probably higher by $60.6 \%(P<0.001)$, the third group was higher by 90.1 ( $P<0.001)$ and the fourth group was higher by $100 \%(P<0.001)$. The obtained results indicate that the meat of broiler chickens of the experimental groups is safe for humans from the point of view of food hygiene because the content of selenium in it does not exceed the maximum permissible level of this trace element for meat which is $1.0 \mathrm{mg} \mathrm{kg}^{-1}$ (Smoljar \& Petrashenko, 2005; Malinin et al., 2007). 
The obtained results are consistent with the conclusions of many scientists who believe that by introducing selenium supplements into the feed diet may to increase its content in the organs and tissues of farm poultry (Cvrtila et al., 2005; Januzi et al., 2019; Silva et al., 2019). However, the data on the effect of selenium supplements in feed on its accumulation in the muscle tissue of poultry are quite contradictory and do not always lend themselves to correct comparison. For example, due to the natural content of selenium in feed $\left(0.09-0.18 \mathrm{mg} \mathrm{kg}^{-1}\right)$ in the muscles of 60-day-old broiler chickens cross "Smena" its level was 16.9 mkg/\% (Japparov \& Rodionova, 2006). The meat of 49-day-old broiler chickens for which during the period of cultivation was enriched mixed fodder with selenium at the rate of 0.2 and $0.3 \mathrm{mg} \mathrm{kg}^{-1}$, contained it on average 5.6 and $8.2 \mathrm{mkg} / \%$ (Rassolov et al., 2008 ). Similar data on the concentration of selenium in muscle tissue $(8.2 \mathrm{mkg} / \%)$ was obtained by researches on broiler chickens of Hubbard Flex cross but when it had introduced into feed at a dose of $0.5 \mathrm{mg} / \mathrm{kg}$ (Ponomarenko, 2007).

Differences in the concentration of selenium in the meat of broiler chickens even at the same doses of its introduction into feed is explained by the difference in geochemical zones and feeding conditions in which researches were conducted the composition of the diet the cross of poultry and unequal availability of trace elements from various chemical compounds.

It should also be noted that the increase in the concentration of selenium in the muscle tissue of poultry of experimental groups were not proportional to its receipt with feed as evidenced by the coefficients of accumulation of this trace element. It is established that with increase levels of selenium in feed the intensity of its biological accumulation in the muscle tissue of broiler chickens decreased (Figure 1). Sufficiently low values of accumulation coefficients $(0.28-0.38)$ indicate that selenium has a weak accumulation capacity in the body of broiler chickens.

Forest-Steppe of Ukraine the rape blossom beetle in the imago stage hibernates on the surface of the soil under the fallen leaves or plant remains on the edges of forests, in gardens and parks. In the course of the inspection and calculations conducted in 20072012 in the experimental fields of the Educational, Research and Production Centre "Research Field" of Kharkiv National Agrarian University named after V.V. Dokuchaiev and the state enterprise "Research Farm "Elitne" of the Institute of Plant Growing named after V.Ya. Yuryiev of the National Academy of Agrarian Sciences of Ukraine we have found out that the first individuals of the rape blossom beetle appear on the flowering plants (first of all dandelion and buttercup) when the average daily temperature passes through the mark $8^{\circ} \mathrm{C}$. The earliest emergence of the beetles on these plants was observed in 2008, 2010 and 2012. The beetles emerged already in the middle of the first decade of April. In 2007 and 2011 the latest period of the beetles' emergence was observed, it was the beginning of the third decade of April (Table 1).

The mass emergence of the rape blossom beetle took place when the average daily temperatures fluctuated within $9-13^{\circ} \mathrm{C}$ and the sum of the effective temperatures above $5^{\circ} \mathrm{C}$ was $100-113^{\circ} \mathrm{C}$. From the data given in Table 1 it is seen that in 2008 the mass emergence of the rape blossom beetles from the hibernation places was in the middle of the second decade of April and it was the earliest during the research period; and in 2009 the beetles emerged at the end of the third decade of April and it was the latest period oh their emergence. After the hibernation the rape blossom beetles feed on the pollen of the flowering vegetation, first on dandelion and buttercup, then on the fruit trees (apricot, plum, cherry and apple) and on the weeds from the cabbage family (colza, hedge mustard and field mustard). According to our observations the active populating of spring oily cabbage crops by the rape blossom beetle took place at the very beginning of the budding phenophase (about the second decade of June), although the solitary individuals have been found since the beginning of the rosette formation (in the second decade of May). With the beginning of the budding phase the population density of the rape blossom beetle in the fields under the oily cabbage crops dynamically increases and reaches its peak before flowering. We noted the beginning of the beetles mating in the third decade of May and at the beginning of the first decade of June; and the laying of eggs was noted beginning from the second decade of June.

At the end of the second and at the beginning of the third decade of June the reappearance of the rape blossom beetle larvae was observed; they fed for about 25-30 days and pupated at the end of the third decade of June and at the beginning of the first decade of July. At the end of the first decade of July the emergence of a new generation of the beetles was noted. In the third decade of June, when the plants are in the phase of the pods formation, the beetles begin to leave the field. The seasonal dynamics of the rape blossom beetle number on spring rape and mustard are shown in the form of diagrams in Figure 1.

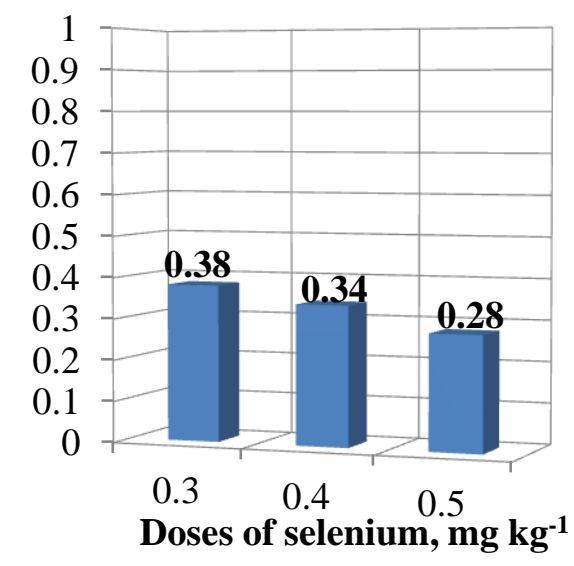

Figure 1. Coefficients of selenium accumulation in the muscle tissue of broiler chickens.

Considering the data obtained it can also be argued that the meat of broiler chickens for which were introduced into the feed additives selenium in the above doses it is a good source of this trace element for humans. Consumption of selenium-enriched meat of broiler chickens within the recommended physiological norms in Ukraine (145 g day ${ }^{-1}$ ) (Postanova Kabinetu Ministriv Ukrai'ny, 2016) should provide the daily requirement of an adult in this trace element (70 mkg) by $23.6-29.4 \%$. Similar calculations can be carried out for the main social and demographic groups of other countries based on the norms of consumption of meat and meat products that force in these countries. 


\section{Conclusion}

Introduction of selenium into the feed for broiler chickens in the doses which are studied $(0.3 \mathrm{mg} / \mathrm{kg}, 0.4 \mathrm{and} 0.5 \mathrm{mg} / \mathrm{kg}) \mathrm{didn}$ 't significantly affect to the quality of their muscle tissue although it positively affected on some indicators that characterizing its chemical composition, nutritional and biological value. Among the experimental groups, the best meat quality indicators were in the second group of chickens for which was introduced into the feed selenium from the calculation of $0.3 \mathrm{mg} / \mathrm{kg}$.

When feeding mixed feeds with selenium additives to broiler chickens it was found that it is likely to increase the concentration of this trace element in muscle tissue by $60.6-100 \%(\mathrm{P}<0.001)$, which doesn't exceed the maximum permissible level (MPL). Consumption of selenium-enriched meat of broiler chickens within the limits of the physiological norms recommended in Ukraine will ensure the daily requirement of an adult in this trace element by $23.6-29.4 \%$. This meat product can be especially useful for people who live in regions with low levels of selenium in the natural environment.

\section{References}

Ashraf, S., Bhatti, S.A., Nawaz, H., \& Khan, M.S. (2019). Assessment of dietary selenium sources in commercial male broiler breeders: effects on semen quality, antioxidant status and immune responses. Pakistan Veterinary Journal, 39(4). doi: 10.29261/pakvetj/2019.081.

Bakaeva, L.N., Topurija, G.M., Topurija, L.Ju., Pol'kin, V.V., \& Rebezov, M.B. (2015). Himicheskij sostav i biologicheskaja cennost' mjasa cypljat-brojlerov pri primenenii selenosoderzhashhej kormovoj dobavki. Vestnik APK Stavropol'ja, 1, 189-192 (in Russian). Boiago, M.M., Borba, H., Leonel, F.R., Giampietro-Ganeco, A., Ferrari, F.B., Stefani, L.M., \& Souza, P.A. (2014). Sources and levels of selenium on breast meat quality of broilers. Ciência Rural, 44(9), 1692-1698. doi: 10.1590/0103-8478cr20131256.

Bokova, T.I., \& Birjukova, S.V. (2007). Ispol'zovanie antioksidantov pri proizvodstve mjasa pticy. Tehnologija i produkty zdorovogo pitanija : sb. materialov mezhdunar. nauch.-prakt. konf. Saratov, 15-16 (in Russian).

Cvrtila, Ž., Kozačinski, L., Hadžiosmanović, M., Milinović-Tur, S., \& Filipović, I. (2005). Značenje selena u mesu peradi. Stočarstvo, 59(4), 281-287. https://hrcak.srce.hr/1972.

DSTU ISO 1442:2005. (2008). M`jaso ta m`jasni produkty. Metod vyznachennja vmistu vologi (kontrol'nyi metod). Kyiv : Derzhstandart Ukrainy (in Ukrainian).

DSTU ISO 1443:2005. (2007). M’jaso ta m’jasni produkty. Metod vyznachennja zagal'nogo vmistu zhyru. Kyiv : Derzhspozhyvstandart Ukrainy (in Ukrainian).

DSTU ISO 936:2008. (2010). M'jaso ta m'jasni produkty. Metod vyznachennja masovoi chastky zagal'noi zoly. Kyiv : Derzhspozhyvstandart Ukrainy (in Ukrainian).

DSTU ISO 937:2005. (2007). M'jaso ta m'jasni produkty. Vyznachennja vmistu azotu (kontrol'nyi metod). Kyiv : Derzhspozhyvstandart Ukrainy (in Ukrainian).

Galibarenko, M., Smirnov, O., Pasichnyj, V., Rjabokon', Ju., Ivko, I., Mel'nyk, B., Pudov, V., Kul'baba, C., Dujunov, B., Sohac'kyj, M., Vashkulat, M., Kyrejeva, I., Bulyga, N., Demydenko, V. (2005). VNTP-APK-04. 05. Pidpryjemstva ptahivnyctva. Kyi'v : Ministerstvo agrarnoi' polityky (in Ukrainian).

GOST 7702.2.0-95. (2009). Mjaso pticy, subprodukty i polufabrikaty ptich'i. Metody otbora prob i podgotovka k mikrobiologicheskim issledovanijam. Moskva : Standartinform (in Russian).

Gutyj, B., Ostapiuk, A., Kachmar, N., Stadnytska, O., Sobolev, O., Binkevych, V., Petryshak, R., Petryshak, O., Kulyaba, O., Naumyuk, A., Nedashkivsky, V., Nedashkivska, N., Magrelo, N., Golodyuk, I., Nazaruk, N., \& Binkevych, O. (2019). The effect of cadmium loading on protein synthesis function and functional state of laying hens' liver. Ukrainian Journal of Ecology, 9(3), 222-226 Holak, W. (1980). Analysis of foods for lead, cadmium, copper, zinc, arsenic, and selenium, using closed system sample digestion: collaborative study. Association of Official Analytical Chemists, 63(3), 485-495.

Januzi, V., Sena, L., \& Elezi, X. (2019). Effect of supplementation of broilers diets with different levels of organic selenium in the quality of carcasses and its concentration in meat and blood. Journal of Multidisciplinary Engineering Science Studies, 5(4), 25652568.

Japparov, I.A., \& Rodionova, T.N. (2006). Vlijanie selena na pokazateli selenovogo obmena u cypljat-brojlerov. Zootehnija, 9, 18-19 (in Russian).

Kornilova, V.A., \& Belova, N.F. (2008). Vlijanie preparata Sel-Pleks v kombikormah dlja cypljat-brojlerov. Izvestija" Samarskoj gosudarstvennoj sel'skohozjajstvennoj akademii, 1, 94-96 (in Russian).

Kruk, Ju., Svezhencov, A.I., \& Musich, O.I. (2007). Jeffektivnost' sel-pleksa v kombikormah dlja kur-nesushek. Ptahivnictvo : mizhvid. temat. nauk. zb., 60(2), 116-119 (in Russian).

Kudrin, A.V., Skal'nyj, A.V., Zhavoronkov, A.A., Skal'naja, M.G., \& Gromova, O.A. (2000). Immunofarmakologija mikrojelementov. Moskva (in Russian).

Lukashenko, V.S. (2013). Metodika provedenija anatomicheskoj razdelki tushek, organolepticheskoj ocenki kachestva mjasa i jaic sel'skohozjajstvennoj pticy i morfologii jaic : metodicheskoe rukovodstvo. VNIITIP. Sergiev Posad (in Russian).

Malinin, O.A., Hmel'nickij, G.A., \& Kucan, A.T. (2002). Veterinarnaja toksikologija. Korsun'-Shevchenkovskij (in Russian).

Metodyka vyznachennja himichnogo skladu ta energetychnoi cinnosti produktiv harchuvannja : zatv. nakazom Derzhdepartamentu z pit. vikonannja pokaran' ta M-va ohorony zdorov'ja Ukrainy vid 18 sichnja 2000 r. № 3/6. Oficijnyi visnyk Ukrainy, 2000, 12, 361 (in Ukrainian).

Mikitjuk, P.V., Bukalova, N.V., Dzhmil', V.I., Hic'ka, O.A., Dzhmil', O.M., Sljusarenko, S.V., \& Utechenko, M.V. (2004). Metodychni vkazivky (mikrometod) shhodo vykorystannja infuzorii Tetrahimena piriformis dlja toksyko-biologichnoi ocinky sil's'kogospodars'kyh produktiv ta vody. Bila Cerkva (in Ukrainian).

Oliveira, T.F.B., Rivera, D.F.R., Mesquita, F.R., Braga, H., Ramos E.M., \& Bertechini, A.G. (2014). Effect of different sources and levels of selenium on performance, meat quality, and tissue characteristics of broilers. The Journal of Applied Poultry Research, 23(1), 15-22. doi: 10.3382/japr.2013-00761.

Ponomarenko, Ju. (2007). Selen i jod v racionah brojlerov. Pticevodstvo, 4, 38-39 (in Russian).

Postanova Kabinetu Ministriv Ukrai'ny. (2016). Pro zatverdzhennja naboriv produktiv harchuvannja, naboriv neprodovol'chyh tovariv ta naboriv poslug dlja osnovnyh social'nyh i demografichnyh grup naselennja (vid 11.10.2016, № 780). Kyi'v (in Ukrainian).

Rassolov, S.N., Glazunova, O.A., \& Eranov, A.M. (2008). Vlijanie selena i joda na himicheskij sostav mjasa sel'skohozjajstvennyh zhivotnyh i pticy, poluchavshih mikrodobavki selena i joda. Kormlenie sel'skohozjajstvennyh zhivotnyh i kormoproizvodstvo, 10, 6770 (in Russian). 
Reilly, C. (2013). Selenium in Food and Health. Springer, Boston. doi: 10.1007/978-0-387-33244-4.

Shackih, E.V. (2009). Fiziologicheskoe obosnovanie ispol'zovanija raznyh form soedinenij selena, joda i cinka v kormlenii cypljatbrojlerov : avtoref. dis. na soiskanie uchen. stepeni d-ra biol. nauk : 03.00 .13 "Fiziologija", 06.02 .02 "Kormlenie sel'skohozjajstvennyh zhivotnyh i tehnologija kormov", Borovsk (in Russian).

Silva, V.A., Bertechini, A.G., Nogueira, B.R.F., Ribeiro, H.V., Mencalha, R., \& Ramos, E.M. (2019). Selenium yeast supplementation for broilers at different ages. The Journal of Applied Poultry Research, pfz063. doi: 10.3382/japr/pfz063.

Smoljar, V.I., \& Petrashenko, G.I. (2005). Alimentarni gipo- ta gipermikroelementozy. Problemy harchuvannja, 4, 40-42 (in Ukrainian).

Sobolev, O., Gutyj, B., Petryshak, R., Pivtorak, J,. Kovalskyi, Y., Naumyuk, A,. Petryshak, O., Semchuk, I., Mateusz, V., Shcherbatyy, A., \& Semeniv B. (2018). Biological role of selenium in the organism of animals and humans. Ukrainian Journal of Ecology, 8(1), 654-665. doi: 10.15421/2017_263.

Sobolev, O., Gutyj, B., Petryszak, R., Golodjuk, I., Naumyuk, O., \& Petryszak, O. (2018). The development of the digestive system in broiler chickens at different levels of selenium into the mixed fodder. Scientific Messenger of Lviv National University of Veterinary Medicine and Biotechnologies, 20(84), 83-87. doi: 10.15421/nvlvet8415

Sobolev, O.I., Gutyj, B.V., Sobolieva, S.V., Shaposhnik, V.M., Sljusarenko, A.A., Stoyanovskyy, V.G., Kamratska, O.I., Karkach, P.M., Bilkevych, V.V., Stavetska, R.V., Babenko, O.I., Bushtruk, M.V., Starostenko, I.S., Klopenko, N.I., Korol'-Bezpala, L.P., Bezpalyi, I.F. (2019) Digestibility of nutrients by young geese for use of lithium in the composition of fodder. Ukrainian Journal of Ecology, 9(1), 1-6.

Sobolev, O.I., Gutyj, B.V., Sobolieva, S.V., Fesenko, V.F., Bilkevych, V.V., Babenko, O.I., Klopenko, N.I., Kachan, A.D., Kosior, L.T., Lastovska, I.O., Vered, P.I., Shulko, O.P., Onyshchenko, L.S., Slobodeniuk, O.I. (2019). The influence of different doses of lithium additive in mixed feed on the balance of nitrogen in organism of goslings. Ukrainian Journal of Ecology, 9(2), 91-96.

Sobolev, O.I., Gutyj, B.V., Darmohray, L.M., Sobolieva, S.V., Ivanina, V.V., Kuzmenko, O.A., Karkach, P.M., Fesenko, V.F., Bilkevych, V.V., Mashkin, Y.O., Trofymchuk, A.M., Stavetska, R.V., Tkachenko, S.V., Babenko, O.I., Klopenko, N.I., Chernyuk, S.V. (2019). Lithium in the natural environment and its migration in the trophic chain. Ukrainian Journal of Ecology, 9(2), $195-203$.

Surai, P., \& Fisinin, V.I. (2014). Selenium in poultry breeder nutrition: An update. Animal Feed Science and Technology, 191. 1-15. doi: $10.1016 /$ j.anifeedsci.2014.02.005.

Suraj, P., \& Papazjan, T. (2007). Prirodnye antioksidanty v kormlenii pticy: uroki prirody. Ptahivnictvo : mizhvidom. temat. nauk. zb., $60(2), 76-82$ (in Russian).

Wang, Y., Zhan, X., Zhang, X., Wu, R., \& Yuan, D. (2011). Comparison of different forms of dietary selenium supplementation on growth performance, meat quality, selenium deposition, and antioxidant property in broilers. Biological Trace Element Research, 143, 261-273. doi: 10.1007 / s12011-010-8839-2.

Yang, Y.R., Meng, F.C., Wang, P., Jiang, Y.B., Yin, Q.Q., Chang, J., Zuo, R.Y., Zheng, Q.H., \& Liu, J.X. (2012). Effect of organic and inorganic selenium supplementation on growth performance, meat quality and antioxidant property of broilers. African Journal of Biotechnology, 11, 3031-3036.

\section{Citation:}

O.I. Sobolev et al. (2019). Chemical composition, energy and biological value of broiler chicken meat caused by various doses of selenium. Ukrainian Journal of Ecology, 9(4), 622-627. 